\title{
Capital Structure of Non-life Insurance Firms in Japan
}

\author{
Mahito Okura ${ }^{1} \&$ Satoru Yamaguchi ${ }^{2}$ \\ ${ }^{1}$ Department of Social System Studies, Faculty of Contemporary Social Studies, Doshisha Women's College of Liberal \\ Arts, Kyoto, Japan. \\ ${ }^{2}$ Faculty of Business Aministration, Konan University, Hyogo, Japan. \\ Correspondence: Mahito Okura, Department of Social System Studies, Faculty of Contemporary Social Studies, \\ Doshisha Women's College of Liberal Arts, Kodo, Kyotanabe, Kyoto, 610-0395, Japan.
}

Received: March 3, 2016

Accepted: March 29, 2016

Available online: March 31, 2016

doi:10.11114/aef.v3i3.1508

URL: http://dx.doi.org/10.11114/aef.v3i3.1508

\begin{abstract}
This research investigates the debt to equity ratio (D/E ratio) in non-life insurance firms in Japan through empirical analysis and offers several main findings. First, the solvency margin ratio has a negative effect on the D/E ratio. Second, neither the Return on Equity (ROE) nor the combined ratio has an impact on the D/E ratio. Third, the expense ratio has a positive effect on the $\mathrm{D} / \mathrm{E}$ ratio, while the loss ratio does not. The second and third results imply that the expense ratio is the most suitable index for measuring profitability in Japan's non-life insurance firms when the D/E ratio is being considered.
\end{abstract}

Keywords: capital structure, debt to equity ratio, non-life insurance, Japan

1. Introduction

The debt to equity ratio (D/E ratio) — debt divided by equity — is critical for evaluating firms' capital structure. A high D/E ratio indicates high bankrupt risk. (Note 1) In contrast, a low D/E ratio indicates poor profitability due to missed revenue opportunities.

However, many studies have (implicitly) investigated non-financial firms because financial firms have different capital structures. (Note 2) Thus, data on financial firms have been excluded from empirical analyses. (Note 3)

Financial firms such as banks and insurance firms have large amounts of debt called "deposits" and "policy reserves," which can cause bankruptcy if not controlled. In fact, many banks and insurance firms went bankrupt during the huge recession caused by the events of the 2008 financial crisis, such as the burst asset price bubbles, the subprime crisis, and the Lehman shock. Thus, regulators in many countries set minimum capital requirements such as BIS banking and solvency margin regulations. Regulators issue orders for improving the financial condition of banks and insurance firms that violate the regulations. At worst, they suspend the offending firm's business operations. The existence of these regulations shows that capital structure problems are very important for financial firms.

This study investigates D/E ratios in non-life insurance firms in Japan. We investigate non-life insurance firms in Japan for three reasons. First, these firms are very large and have huge debt and equity. The General Insurance in Japan Fact Book 2013-2014 states that Japanese non-life insurance firms have debt and equity of 23,116 billion yen (about US201.01 billion) and 5813.7 billion yen (about US50.55 billion), respectively. (Note 4) Second, Japan's non-life insurance firms are relatively easy to compare because they all have stock forms, whereas some Japan's large life insurance firms have mutual forms; their capital structure is thus fundamentally different because mutual forms do not issue their stocks, and they have little capital. Third, non-life insurance firms have the appropriate variables that are likely to affect D/E ratios. For example, all non-life insurance firms disclose their combined ratio - the sum of total losses and expenses divided by written premiums. A combined ratio of less than 100 percent below (above) indicates that the non-life insurance firm has profited (lost) from underwriting. Thus, the combined ratio represents the profitability of non-life insurance firms, making it worthwhile to investigate how the combined ratio in each firm affects its $\mathrm{D} / \mathrm{E}$ ratio.

This paper is organized as follows. Section 2 introduces the variables used in our empirical analysis. The data are explained in Section 3. Section 4 presents the empirical results. Section 5 concludes the paper.

\section{Variables}

We apply the independent variables described below to investigate what kinds of variables impact the D/E ratio through empirical analysis.

First, the D/E ratio is expected to be affected by size, which can be measured as the amount of assets. The size of each non-life insurance firm is expected to have both positive and negative effects on D/E ratios. An increase in the size of a non-life insurance firm raises not only equity from the capital market but also debt from the lending market. Thus, we 
cannot confirm whether the size effect will be positive or negative in advance.

Second, the D/E ratio is expected to be affected by ability to pay for insurance money, one of the indexes of which is the solvency margin ratio, disclosed in Japan since fiscal 1998. When the solvency margin ratio reaches below 200 percent, Japan's Financial Services Agency, the insurance industry regulator, either tries to improve business operations or suspends them. The solvency margin ratio is the solvency margin divided by half of the degree of the risk of unexpected losses. A high solvency margin ratio represents a high solvency margin and/or a low level of risk. We expect that the solvency margin ratio has a negative effect on the $\mathrm{D} / \mathrm{E}$ ratio.

Third, the D/E ratio is expected to be affected by the profitability of the non-life insurance firms. The profitability effect is examined using two profitability variables, Return on Equity (ROE) and the combined ratio.

We can expect that ROE has a negative effect on D/E ratios because high ROE indicates large equity and/or low debt. The combined ratio indicates profitability in the insurance industry, reflecting incurred losses plus total expenses divided by the written premium. (Note 5) Thus, a low combined ratio indicates high profitability in a non-life insurance firm. We can expect that the combined ratio has a positive effect on the D/E ratio because high profitability leads to increased surpluses, which are included in firm equity. The combined ratio consists of the loss and expense ratios: the loss ratio is the incurred loss divided by the written premium, while the expense ratio comprises total expenses - including commissions, collection fees, and sales and administrative expenses-divided by the written premium. We can expect that the loss ratio does not affect the D/E ratio because the amount of incurred loss depends mainly on accident probability, which seems to be common and exogenous across all non-life insurance firms. However, we can expect that the expense ratio has a positive effect on the D/E ratio because total expenses can change according to the management decisions made in each non-life insurance firm, such as reducing unnecessary costs and introducing more efficient operating systems.

Fourth, all non-life insurance firms can reduce their risk of insurance money payment through the reinsurance market. Harrington and Niehaus (2003, p. 89) argue that "the purchase of reinsurance can substitute for capital and allow an insurer to hold less capital without increasing its insolvency probability." Thus, the reinsurance ratio, which measures the reinsurance premiums paid divided by the net premiums written, has a positive effect on the D/E ratio. By contrast, Dofrman (2008, p. 400) claims that "reinsurance reduces the primary insurer's need to maintain loss and unearned premium reserves. When the primary insurer purchases reinsurance, it reduces the size of its potential loss and thereby reduces the size of the reserves it must maintain." The reinsurance ratio can thus be expected to have a negative effect on the $\mathrm{D} / \mathrm{E}$ ratio. Thus, whether the reinsurance effect is positive or negative cannot be known in advance.

Finally, the D/E ratio may depend on whether each non-life insurance firm is listed on the stock market because listed firms raise their equity by issuing stocks. Thus, listed non-life insurance firms may finance their equity more easily than unlisted firms can.

However, all non-life insurance firms became unlisted after Fuji Fire \& Marine Insurance was delisted in July 2011. There are two ways to be unlisted. The first is to become a member of a holding firm. For example, Sonpo Japan Insurance delisted on March 29, 2010, and established a holding firm (NKSJ holding) with Nipponkoa Insurance on April 1, 2010. The second way is to be founded as a subsidiary and to never be listed. For example, AXA General Insurance was founded as a member of the AXA group, with all of its stock owned by AXA Life Insurance (as of June 2015). Unlisted non-life insurance firms would finance their debt and equity more easily than listed firms would because their holding or parent firms have huge resources with which to finance them. To examine this possibility, we use dummy variable which takes 1 if the non-life insurance firm lists and 0 otherwise. In the end, it seems whether listed or non-listed non-life insurance firms have ambiguous effect to D/E ratio.

\section{The Data}

We collect non-life insurance firms' financial data from the Corporate Financial Data (TANSHIN/YUHO) Database maintained by the Nikkei Electronic Databank System (NEEDS). This database provides corporate financial data submitted via yuho (or yuka shoken hokokusho, Japanese financial statements) on listed and unlisted firms as well as on firms whose financial statements are disclosed in the yuho of their parent firms.

This empirical research starts in January 1999 because the Commercial Law was revised in 1999, requiring insurance firms to disclose their solvency margin ratios. First, we identify all the non-life insurance firms with reported asset values from January 1999 to December 2012. We exclude reinsurance and financial holding firms from our sample. The result consists of 26 non-life insurance firms and 199 firm-year observations. Second, to reduce endogeneity, we regress $\mathrm{D} / \mathrm{E}$ at period $t$ on independent variables at period $t-1$. We also exclude observations for which we are unable to calculate each variable because of missing values. Finally, to avoid having outliers obscure our results, we exclude all variables with 1 percent tails. After these reductions, 98 firm-year observations for 16 non-life insurance firms were left. (Note 6) 
Table 1. Summary Statistics

\begin{tabular}{cccccc}
\hline Variables & Mean & $1^{\text {st }}$ Quartile & Median & $3^{\text {rd }}$ Quartile & SD \\
\hline LEV & 5.950 & 3.612 & 4.844 & 6.770 & 3.753 \\
SIZE & 14.495 & 13.890 & 14.715 & 15.431 & 1.080 \\
ROE & -0.009 & 0.017 & 0.026 & 0.042 & 0.159 \\
SOLV & 937.479 & 760.100 & 949.300 & 1110.900 & 243.779 \\
COMB & 0.969 & 0.939 & 0.968 & 1.007 & 0.055 \\
LOSS & 0.360 & 0.335 & 0.354 & 0.376 & 0.039 \\
EXPENSE & 0.609 & 0.579 & 0.607 & 0.648 & 0.053 \\
REINS & 0.190 & 0.176 & 0.192 & 0.210 & 0.022 \\
\hline
\end{tabular}

Table 1 shows the summary statistics. LEV is debt divided by equity measured at period $t$. SIZE is the natural logarithm of assets. ROE is net income divided by equity. SOLV is the solvency margin ratio. COMB is the combined ratio. LOSS and EXPENSE are loss ratio and expense ratio, respectively. REINS is the reinsurance premiums paid divided by net premiums written. All independent variables are measured at period $t-1$. We use a dummy variable to represent whether each non-life insurance firm lists at period $t$; it is equal to 1 if the non-life insurance firm lists and 0 otherwise.

\section{Empirical Results}

Table 2 presents the correlation coefficients between our variables. It shows that SIZE is strongly negatively correlated with LOSS and that COMB is strongly positively correlated with EXPENSE, which explains about 70 percent of the variability of COMB.

Table 3 reports the regression results. We calculate $t$ values using standard errors allowing heteroscedasticity and clustering by firm. The results of Model 1 show that SIZE and SOLV have statistically significant impacts on the D/E ratio at 1 percent significance level. The negatively significant coefficient of SIZE suggests that D/E ratios decrease as non-life insurance firms grow. The coefficient of SOLV is also significantly negative, implying that non-life insurance firms have lower D/E ratios when at higher risk of bankruptcy.

Table 2. Correlation coefficients

\begin{tabular}{ccccccccc}
\hline & LEV & SIZE & ROE & SOLV & COMB & LOSS & EXPENSE REINS \\
\hline LEV & 1.000 & & & & & & & \\
SIZE & -0.556 & 1.000 & & & & & & \\
ROE & -0.276 & 0.309 & 1.000 & & & & & \\
SOLV & -0.539 & 0.278 & 0.261 & 1.000 & & & & \\
COMB & 0.448 & -0.129 & -0.057 & -0.357 & 1.000 & & & \\
LOSS & 0.725 & -0.747 & -0.284 & -0.325 & 0.401 & 1.000 & & \\
EXPENSE & -0.079 & 0.424 & 0.153 & -0.126 & 0.731 & -0.332 & 1.000 & \\
REINS & -0.289 & 0.183 & 0.045 & 0.156 & -0.542 & -0.421 & -0.245 & 1.000 \\
\hline
\end{tabular}

Table 3. The results of the linear regression model

\begin{tabular}{|c|c|c|c|c|}
\hline \multirow[b]{3}{*}{ Independent Variable } & \multicolumn{4}{|c|}{ Dependent Variable: Debt/Equity } \\
\hline & \multicolumn{2}{|c|}{ Modell } & \multicolumn{2}{|c|}{ Model2 } \\
\hline & Coef & $\mathrm{t}$ value & Coef & $\mathrm{t}$ value \\
\hline SIZE & -1.468 & $-3.35 * * *$ & -0.112 & -0.23 \\
\hline ROE & -0.986 & -0.40 & -0.537 & -0.20 \\
\hline SOLV & -0.005 & $-2.37 * * *$ & -0.005 & $-3.19 * * *$ \\
\hline COMB & 17.926 & 1.70 & & \\
\hline LOSS & & & 10.920 & 1.30 \\
\hline EXPENSE & & & 65.660 & $3.69 * * *$ \\
\hline REINS & -2.796 & -0.14 & 15.270 & 0.97 \\
\hline Dummy & -0.421 & -0.57 & 0.129 & 0.19 \\
\hline Intercept & 14.951 & 1.15 & -21.390 & -1.36 \\
\hline Obs & \multicolumn{2}{|c|}{98} & \multicolumn{2}{|c|}{98} \\
\hline Adjusted R squared & \multicolumn{2}{|c|}{0.5116} & \multicolumn{2}{|c|}{0.6165} \\
\hline
\end{tabular}

Note: $* * * * *$, and $*$ represent significance at the $10 \%, 5 \%$, and $1 \%$ levels, respectively.

In Model 2, we break COMB down into LOSS and EXPENSE. Although COMB does not have a significant impact on D/E ratio in Model 1, EXPENSE is statistically positively significant, while LOSS is not statistically significant. This result has two implications. First, we find that EXPENSE is the most suitable factor for measuring the profitability of 
non-life insurance firms when their capital structure problem is considered because neither ROE nor COMB has a significant impact on the D/E ratio. Second, it appears that the D/E ratio is decided not by LOSS, which seems to be exogenous, but by EXPENSE, which seems to be endogenous.

Moreover, SIZE becomes insignificant in Model 2. The factor affecting non-life insurance firms' capital structure seems to be not asset size but profitability (EXPENSE), perhaps indicating that non-life insurance firms design their capital structures from the risk and return perspectives.

REINS has no statistical impact on the D/E ratio in either model. It seems that reinsurance both increases and decreases D/E ratios, as explained above, and these effects are expected to cancel each other out.

Dummy is also statistically insignificant in both models. This result shows that even if the non-life insurance firms list, $\mathrm{D} / \mathrm{E}$ ratio is not statistically different from unlisted non-life insurance firms. It seems that holding and parent firms may have an alternative function of listing to decide D/E ratio.

\section{Concluding Remarks}

This research investigated the debt to equity ratio (D/E ratio) in non-life insurance firms in Japan through empirical analysis and produced several main findings. First, the solvency margin ratio has a negative effect on the D/E ratio. Second, neither the Return on Equity (ROE) nor the combined ratio has an impact on the D/E ratio. Third, the expense ratio has a positive effect on the $\mathrm{D} / \mathrm{E}$ ratio, while the loss ratio does not. The second and third results imply that the expense ratio is the most suitable index for measuring profitability in Japan's non-life insurance firms when the D/E ratio is being considered.

This research could be extended in several ways. For example, this study focused on non-life insurance firms; D/E ratios in Japanese life insurance firms could be analyzed in a similar way. However, doing so would involve three difficulties. First, some life insurance firms have a mutual form. These mutual insurance firms have very different D/E ratios because they cannot issue stocks. Three of Japan's large life insurance firms (Nippon, Sumitomo, Meiji Yasuda) are mutual. Second, the concept of the combined ratio (comprising the loss and expense ratios) does not exist for life insurance firms, and reinsurance has little impact on the life insurance market. (Note 7) Thus, some of the independent variables used in this research could not be employed. Third, seven of Japan's life insurance firms, but only one non-life insurance firm, went bankrupt during the study period of this research, indicating that some kind of adjustment for bankruptcies is needed.

\section{Acknowledgements}

This work was supported by JSPS KAKENHI Grant Number 24730362 (Mahito Okura).

\section{References}

Baker, M., \& Wurgler, J. (2002). Market Timing and Capital Structure. Journal of Finance, 57(1), 1-32. http://dx.doi.org/10.1111/1540-6261.00414

Brealy, R. A., Myers, S. C., \& Allen, F. (2010). Principles of Corporate Finance (10 ${ }^{\text {th }}$ edition), New York: McGraw-Hill.

Dorfman, M. S. (2008). Introduction to Risk Management and Insurance ( $9^{\text {th }}$ edition), New Jersey: Pearson Prentice Hall.

Fama, E. F., \& French, K. R. (2002). Testing Trade-off and Pecking Order Predictions about Dividends and Debt. Review of Financial Studies, 15(1), 1-33. http://dx.doi.org/10.1093/rfs/15.1.1

Harrington, S. E. and Niehaus, G. R. (2003). Risk Management and Insurance ( $2^{\text {nd }}$ edition), New York: McGraw-Hill.

Lin, L. and Flannery, M. J. (2013). Do Personal Taxes Affect Capital Structure? Evidence from the 2003 Tax Cut. Journal of Financial Economics, 109, 549-565. http://dx.doi.org/10.1016/j.jfineco.2013.03.010

Tirole, J. (2006). The Theory of Corporate Finance, Princeton: Princeton University Press.

\section{Notes}

Note 1. For details, see Brealy et al. (2010, pp. 447-452).

Note 2. For example, Tirole (2006, p. 79) argued that "Many financial intermediaries (banks, insurance companies, pension funds, mutual funds) are subject to regulatory requirements, which penalize them for holding certain types of asset or even prohibit them from doing so."

Note 3. Studies that omit financial firms include Fama and French (2002, pp. 8-9), Baker and Wurgler (2002, pp. 4-5), and Lin and Flannery (2013, pp. 554-555).

Note 4. See the following website (p.7): http://www.sonpo.or.jp/en/publication/pdf/fb2014e.pdf (accessed February 26, 2016). 
Note 5. The explanation of the combined ratio that follows is greatly indebted to Dorfman (2008, pp. 10-11).

Note 6. Taisei Fire \& Marine Insurance went bankrupt in November 2011. However, our restriction criteria removed its data from the sample. This firm was the only firm to go bankrupt during the study period.

Note 7. For example, according to the annual report of Nippon Life, Japan's leading life insurance firm, insurance revenue was $5,337,118$ million yen, but reinsurance premiums totaled only 1,491 million yen ( 0.028 percent) in fiscal 2014. By contrast, according to the annual report of Tokio Marine \& Nichido Fire Insurance, Japan's leading non-life insurance firm, insurance revenue was 2,512,200 million yen, while reinsurance premiums totaled 475,410 million yen (18.92 percent).

\section{(c) $\mathrm{BY}$}

This work is licensed under a Creative Commons Attribution 3.0 License. 